\title{
Toxic effects of ammonia exposure on growth performance, hematological parameters, and plasma components in rockfish, Sebastes schlegelii, during thermal stress
}

\author{
Ki Won Shin², Shin-Hu Kim¹, Jun-Hwan Kim, Seong Don Hwang ${ }^{2}$ and Ju-Chan Kang ${ }^{1 *}$
}

\begin{abstract}
Rockfish, Sebastes schlegelii (mean length $14.53 \pm 1.14 \mathrm{~cm}$ and mean weight $38.36 \pm 3.45 \mathrm{~g}$ ), were exposed for 4 weeks with the different levels of ammonia in the concentrations of $0,0.1,0.5$, and $1.0 \mathrm{mg} / \mathrm{L}$ at 19 and $24^{\circ} \mathrm{C}$. The indicators of growth performance such as daily length gain, daily weight gain, condition factor, and hematosomatic index were significantly reduced by the ammonia exposure and high temperature. The ammonia exposure induced a significant decrease in hematological parameters, such as red blood cell (RBC) count, white blood cell (WBC) count, hemoglobin $(\mathrm{Hb})$, and hematocrit $(\mathrm{Ht})$, whose trend was more remarkable at $24^{\circ} \mathrm{C}$. Mean corpuscular volume (MCV), mean corpuscular hemoglobin (MCH), and mean corpuscular hemoglobin concentration (MCHC) were also notably decreased by the ammonia exposure. Blood ammonia concentration was considerably increased by the ammonia concentration exposure. In the serum components, the glucose, glutamic oxalate transaminase (GOT), and glutamic pyruvate transaminase (GPT) were substantially increased by the ammonia exposure, whereas total protein was significantly decreased. But, the calcium and magnesium were not considerably changed.
\end{abstract}

Key words: Ammonia, Hematological parameters, Growth performance, Plasma components, Rockfish

\section{Background}

Ammonia is one of the nitrogenous wastes especially in water. It is generated from the catabolism of amino acids, purines, and pyrimidines (Ruyet et al. 1995). In an aquatic environment, ammonia exists as two main forms such as unionized ammonia $\left(\mathrm{NH}_{3}\right)$ and ionized ammonium $\left(\mathrm{NH}_{4}^{+}\right)$(Randall and Tsui 2002). The toxicity of ammonia is significantly affected by the levels of $\mathrm{pH}$; the increase in $\mathrm{pH}$ induces the concentration of $\mathrm{NH}_{3}$ increase (Richardson 1997). The toxic effects of ammonia exposure to aquatic animals strongly occur by the high concentration of unionized ammonium $\left(\mathrm{NH}_{3}\right)$ because it can readily diffuse through the gill membranes (Sinha et al. 2012). Excessive ammonia can cause the growth

\footnotetext{
* Correspondence: jckang@pknu.ac.kr

${ }^{1}$ Department of Aquatic Life Medicine, Pukyong National University, Busan 608-737, Republic of Korea

Full list of author information is available at the end of the article
}

performance decrease, tissue erosion and degeneration, immune suppression, and high mortality in aquatic animals, which acts as toxicity by increasing ammonia levels in blood and tissues (Lemarie et al. 2004; Li et al. 2014). In addition, the ammonia exposure also induces the neurotoxicity, oxidative stress, and oxygen delivery impairment as well as hyperactivity, convulsions, and coma (Wilkie 1997).

Ammonia toxicity can be affected by various environmental parameters like temperature, $\mathrm{pH}$, salinity, and oxygen (Lemarie et al. 2004). Among the environmental indicators, temperature is one of the most major parameters to influence ammonia toxicity, and Richardson (1997) reported that the temperature increase caused a significant elevation in ammonia toxicity. Generally, the increase in temperature in aquatic animals induces the higher toxic effects under toxicity exposure (Patra et al. 2015), because the high temperature elevates the 
diffusion rate, bioavailability, and chemical reactions of the aquatic animals (Delos and Erickson 1999). Barbieri and Bondioli (2015) also reported the lower $\mathrm{LC}_{50}$ for the ammonia exposure of Pacu fish, Piaractus mesopotamicus by increasing water temperature, which means that the higher temperature causes the higher ammonia toxicity.

The exposure to toxic substances in aquatic environment can induce the negative effects on reproduction and growth performance in fish (Kim and Kang 2015). Among various toxicants, ammonia is one of the most toxic substances to cause the growth inhibition in fish farming, and the ammonia toxicity can be a main reason in fish mortality (El-Shafai et al. 2004). Given that the toxicants generally inhibit the growth performance in aquatic animals, the growth performance can be a good indicator to assess the toxicity in the animals.

Considering the exposure to toxicants induces the alterations of fish blood indicators, the hematological parameters can be a sensitive and reliable indicator to assess the toxicity on the exposed animals (Kim and Kang 2014). The ammonia exposure negatively causes the alterations in blood chemistry in aquatic animals as well as the decrease in reproductive capacity and growth rate (Vosyliene and Kazlauskiene 2004). Ajani (2008) reported a significant decrease in blood parameters such as red blood cell (RBC) counts, hemoglobin, and hematocrit of African catfish, Clarias gariepinus, exposed to ammonia, which may be due to anemia and haemodilution of haemolysis for RBC.

Rockfish, Sebastes schlegelii, is a commonly cultured fish in the marine net cages of South Korea because of its rapid growth performance and high demand, which is one of the three largest cultured fish in South Korea. But, the study about the ammonia exposure depending on water temperature has insufficiently been conducted, although the ammonia is ubiquitous in the marine net cages and highly toxic to cultured animals. Therefore, the purpose of this study was to evaluate the toxic effects for the ammonia exposure depending on water temperature to the S. schlegelii on hematological parameters and plasma components.

\section{Methods}

\section{Experimental animals and conditions}

Rockfish, S. schlegelii (mean length $14.53 \pm 1.14 \mathrm{~cm}$ and mean weight $38.36 \pm 3.45 \mathrm{~g}$ ), were obtained from a commercial farm (Tongyeong, Korea). Fish were held for 3 weeks in seawater at $19{ }^{\circ} \mathrm{C}$ to ensure that all individuals were healthy and feeding, and also to reset the thermal history (19 and $24{ }^{\circ} \mathrm{C}$ ) of the animals prior to initiating temperature acclimations (temperature; $19.0 \pm$ 0.6 and $23 \pm 0.5{ }^{\circ} \mathrm{C}, \mathrm{pH} ; 7.9 \pm 0.6$, salinity; $33.1 \pm 0.5 \%$, dissolved oxygen; $7.4 \pm 0.5 \mathrm{mg} / \mathrm{L}$ ). The fish were fed a commercial diet twice daily (Woosung Feed, Daejeon City, Korea). The water temperature was adjusted from ambient at a rate of $\pm 1{ }^{\circ} \mathrm{C}$ /day until a final temperature of $24{ }^{\circ} \mathrm{C}$ was reached. The acclimation period commenced once the final temperature had been sustained for $24 \mathrm{~h}$ and animals were feeding while showing no sign of stress. Ammonia exposure took place in 40-L glass tanks containing 13 fish per treatment group. Ammonia chloride $\left(\mathrm{NH}_{4} \mathrm{Cl}\right)$ (Sigma, St. Louis, $\mathrm{MO}$, USA) solution was dissolved in the respective glass tanks. The annual report on marine environment monitoring in Korea 2014 showed the ammonia levels $0.46 \mathrm{mg} / \mathrm{L}$ in Gunsan, $0.64 \mathrm{mg} / \mathrm{L}$ in Ulsan, and $1.39 \mathrm{mg} / \mathrm{L}$ in Busan during the summer season. By our surveying of the fish farm in Tongyeong, it showed the over $0.5 \mathrm{mg} / \mathrm{L}$ ammonia level in summer. Therefore, our studies established the experimental concentrations of ammonia 0, 0.1, 0.5, and $1.0 \mathrm{mg} / \mathrm{L}$. The ammonia concentrations in the glass tanks were $0,0.1,0.5$, and $1.0 \mathrm{mg} / \mathrm{L}$, and the actual ammonia concentration is demonstrated in Table 1. The glass tank water was thoroughly exchanged once per 2 days and made the same concentration in the respective glass tank. At the end of each period (at 2 and 4 weeks), animals were anesthetized in buffered 3aminobenzoic acid ethyl ester methane sulfonate (Sigma Chemical, St. Louis, MO).

\section{Growth performance}

The weight and length of rockfish were measured just before exposure, at 2 and 4 weeks. Daily length gain, daily weight gain, condition factor, and Hepatosomatic Index (HIS) were calculated by the following method.

Daily growth gain $=\mathrm{W}_{\mathrm{f}}-\mathrm{W}_{\mathrm{i}} /$ day

$\left(\mathrm{W}_{\mathrm{f}}=\right.$ final or weight, $\mathrm{W}_{\mathrm{i}}=$ Initial length or weight $)$

Condition factor $(\%)=\left(\mathrm{W} / \mathrm{L}^{3}\right) \times 100$

$(\mathrm{W}=\operatorname{weight}(\mathrm{g}), \mathrm{L}=$ length $(\mathrm{cm}))$

HIS $=($ liver weight $/$ total fish weight $) \times 100$

\section{Hematological parameters}

Blood samples were collected within 35-40 s through the caudal vein of the fish in 1-mL disposable heparinized syringes. The blood samples were kept at $4{ }^{\circ} \mathrm{C}$ until the blood parameters were completely studied. The total

Table 1 Analyzed waterborne ammonia concentration from each source

Ammonia concentration (mg/L)

\begin{tabular}{lllll}
\hline Ammonia levels & 0 & 0.1 & 0.5 & 1.0
\end{tabular}

\begin{tabular}{lllll} 
Actual ammonia levels & 0.05 & 0.18 & 0.67 & 1.21 \\
\hline
\end{tabular} 
red blood cell (RBC) count, white blood cell (WBC), hemoglobin $(\mathrm{Hb})$ concentration, and hematocrit $(\mathrm{Ht})$ value were determined immediately. Total RBC and WBC counts were counted using an optical microscope with a hemocytometer (Improved Neubauer, Germany) after being diluted with Hendrick's diluting solution. The $\mathrm{Hb}$ concentration was determined using the cyanmethemoglobin technique (Asan Pharm. co., Ltd.). The Ht value was determined by the microhematocrit centrifugation technique. Erythrocyte indices like mean corpuscular volume (MCV), mean corpuscular hemoglobin $(\mathrm{MCH})$, and mean corpuscular hemoglobin concentration $(\mathrm{MCHC})$ were also calculated according to standard formulas.

$$
\begin{aligned}
& \operatorname{MCV}(\mathrm{fl})=\frac{\mathrm{Ht}(\%) \times 10}{\operatorname{RBC}\left(10^{6} / \mathrm{uL}\right)} \\
& \operatorname{MCH}(\mu \mu \mathrm{g})=\frac{\mathrm{Hb}(\mathrm{g} / \mathrm{dL}) \mathrm{X} 10}{\operatorname{RBC}\left(10^{6} / \mathrm{uL}\right)} \\
& \operatorname{MCHC}(\%)=\frac{\mathrm{Hb}(\mathrm{g} / \mathrm{dL}) \mathrm{X} 100}{\mathrm{Ht}(\%)}
\end{aligned}
$$

\section{Serum components}

The blood samples were centrifuged to separate serum from blood samples at $3000 \mathrm{~g}$ for $5 \mathrm{~min}$ at $4{ }^{\circ} \mathrm{C}$. The serum samples were analyzed for inorganic substances, organic substances and enzyme activity using clinical kit (Asan Pharm. Co., Ltd.). In inorganic substances assay, calcium and magnesium were analyzed by the o-cresolphthalein complexone technique and xylidyl blue technique. In an organic substance assay, glucose and total protein were analyzed by GOD/POD technique and biuret technique. In an enzyme activity assay, glutamic oxalate transaminase (GOT) and glutamic pyruvate transaminase (GPT) were analyzed by Kind-King technique using a clinical kit.

\section{Blood ammonia concentration}

Blood samples were collected within 35-40 s through the caudal vein of the fish in 1-mL disposable heparinized syringes. The blood samples were kept at $4{ }^{\circ} \mathrm{C}$ until the blood ammonia was completely studied. The blood ammonia was determined by indophenol method using a clinical kit (Asan Pharm. Co.,Ltd.).

\section{Statistical analysis}

The experiment was conducted in exposure periods for 4 weeks and performed triplicate. Statistical analyses were performed using the SPSS/PC+ statistical package (SPSS Inc, Chicago, IL, USA). Significant differences between groups were identified using one-way ANOVA and Duncan's test for multiple comparisons or Student's $t$ test for two groups (Duncan, 1955). The significance level was set at $P<0.05$.

\section{Results \\ Growth performance}

The indicators of the growth performance of S. schlegelii such as daily length gain, daily weight gain, condition factor, and hepatosomatic index are demonstrated in Fig. 1. In daily length gain, a notable reduction was observed over $0.5 \mathrm{mg} / \mathrm{L}$ at 19 and $24{ }^{\circ} \mathrm{C}$ after 2 weeks. After 4 weeks, the daily length gain was significantly decreased over $0.5 \mathrm{mg} / \mathrm{L}$ at $19{ }^{\circ} \mathrm{C}$ and over control at $24{ }^{\circ} \mathrm{C}$. In daily weight gain, a considerable decrease was observed over $0.5 \mathrm{mg} / \mathrm{L}$ at 19 and $24{ }^{\circ} \mathrm{C}$. After 4 weeks, the daily weight gain was markedly reduced over $0.5 \mathrm{mg} / \mathrm{L}$ at $19{ }^{\circ} \mathrm{C}$ and over $0.1 \mathrm{mg} / \mathrm{L}$ at $24{ }^{\circ} \mathrm{C}$. The condition factor after 2 weeks was substantially decreased in the concentration of $1.0 \mathrm{mg} / \mathrm{L}$ at 19 and $24{ }^{\circ} \mathrm{C}$, and a considerable decrease after 4 weeks was observed in the concentration in $1.0 \mathrm{mg} / \mathrm{L}$ at $19{ }^{\circ} \mathrm{C}$ and over $0.5 \mathrm{mg} / \mathrm{L}$ at $24{ }^{\circ} \mathrm{C}$. In the Hepatosomatic Index, a significant reduction was observed in the concentration of $1.0 \mathrm{mg} / \mathrm{L}$ at $19{ }^{\circ} \mathrm{C}$ and over $0.5 \mathrm{mg} / \mathrm{L}$ at $24{ }^{\circ} \mathrm{C}$. After 4 weeks, the Hepatosomatic Index was notably decreased over $0.5 \mathrm{mg} / \mathrm{L}$ at 19 and $24{ }^{\circ} \mathrm{C}$. In the growth performance, the growth indicators affected the concentration of ammonia exposure and temperature.

\section{Hematological parameters}

The hematological parameters (RBC count, WBC count, $\mathrm{Hb}$, and $\mathrm{Ht}$; MCV, $\mathrm{MCH}$, and $\mathrm{MCHC}$ ) of S. schlegelii is demonstrated in Figs. 2 and 3. In RBC count, a notable decline was shown in the concentration of $1.0 \mathrm{mg} / \mathrm{L}$ at $19{ }^{\circ} \mathrm{C}$ and over $0.5 \mathrm{mg} / \mathrm{L}$ at $24{ }^{\circ} \mathrm{C}$ after both 2 and 4 weeks. In WBC count, a substantial decrease was observed over $0.5 \mathrm{mg} / \mathrm{L}$ at $19{ }^{\circ} \mathrm{C}$ and over $0.1 \mathrm{mg} / \mathrm{L}$ at $24{ }^{\circ} \mathrm{C}$ after 2 weeks. After 4 weeks, the WBC count was markedly increased in the concentration of $1.0 \mathrm{mg} / \mathrm{L}$ at $19{ }^{\circ} \mathrm{C}$ and over $0.1 \mathrm{mg} / \mathrm{L}$ at $24{ }^{\circ} \mathrm{C}$. In hemoglobin, a significant decrease was observed in the concentration of $1.0 \mathrm{mg} / \mathrm{L}$ at $19{ }^{\circ} \mathrm{C}$ and over $0.5 \mathrm{mg} / \mathrm{L}$ at $24{ }^{\circ} \mathrm{C}$ after 2 weeks. After 4 weeks, the $\mathrm{Hb}$ concentration was decreased over $0.5 \mathrm{mg} / \mathrm{L}$ of ammonia exposure. In hematocrit, a considerable decrease was observed in the concentration of $1.0 \mathrm{mg} / \mathrm{L}$ at $19{ }^{\circ} \mathrm{C}$ and over $0.5 \mathrm{mg} / \mathrm{L}$ at $24{ }^{\circ} \mathrm{C}$ after both 2 and 4 weeks. The values of $\mathrm{RBC}$ count, WBC count, $\mathrm{Hb}$, and $\mathrm{Ht}$ were notably decreased by the ammonia exposure, and the high temperature catalyzed the decline in the values.

In $\mathrm{MCV}$ value, a significant decrease was observed in the concentration of $1.0 \mathrm{mg} / \mathrm{L}$ at $19{ }^{\circ} \mathrm{C}$ and over $0.5 \mathrm{mg} /$ $\mathrm{L} 24{ }^{\circ} \mathrm{C}$ after 2 and 4 weeks. The $\mathrm{MCH}$ value was considerably decreased in the concentration of $1.0 \mathrm{mg} / \mathrm{L}$ at $19{ }^{\circ} \mathrm{C}$ and over $0.5 \mathrm{mg} / \mathrm{L} 24{ }^{\circ} \mathrm{C}$ after 2 and 4 weeks. In 

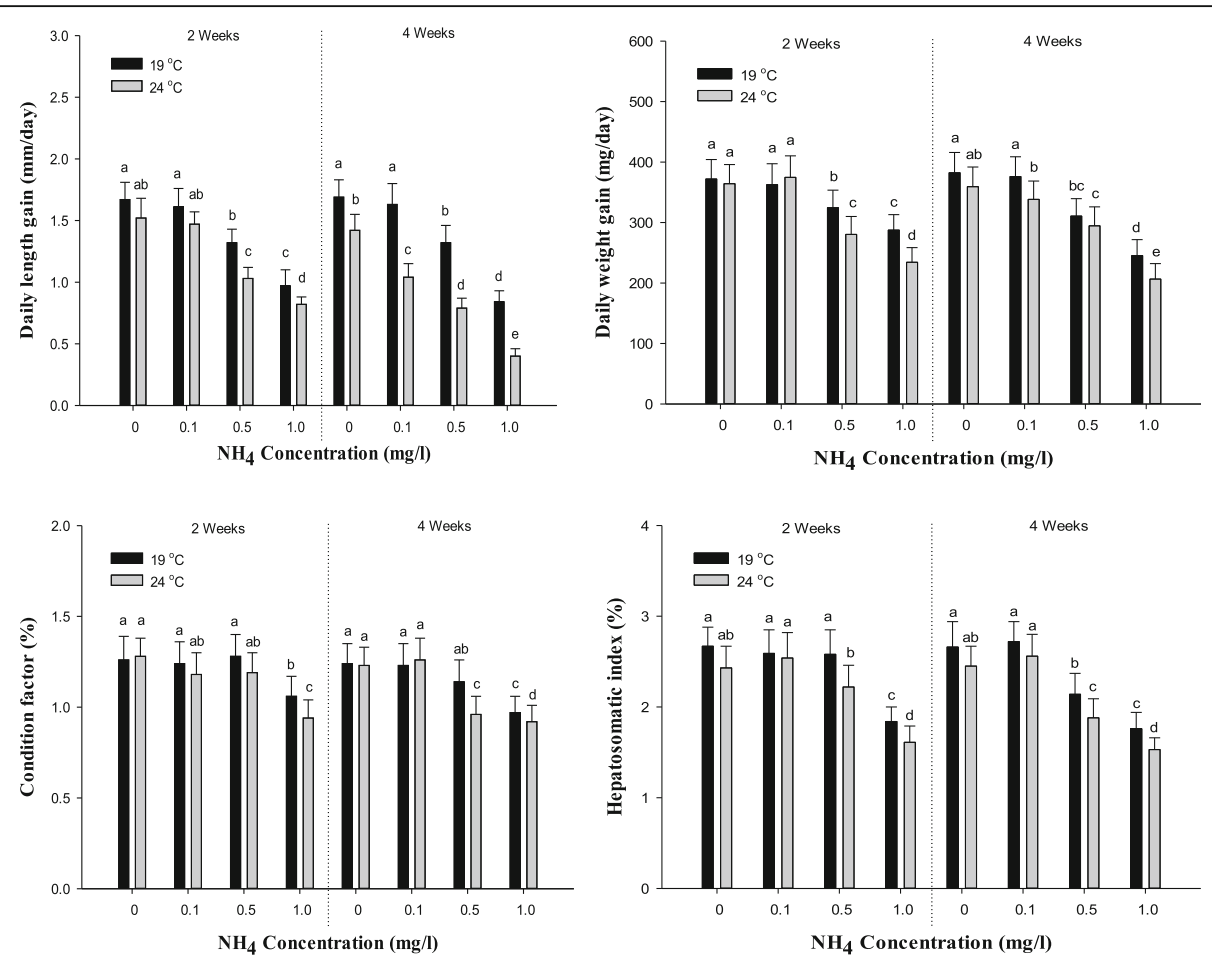

Fig. 1 Change of growth rate in rockfish, Sebastes schlegelii, exposed to the different ammonia concentrations and water temperatures. Values with different superscripts are significantly different $(P<0.05)$ as determined by Duncan's multiple range test
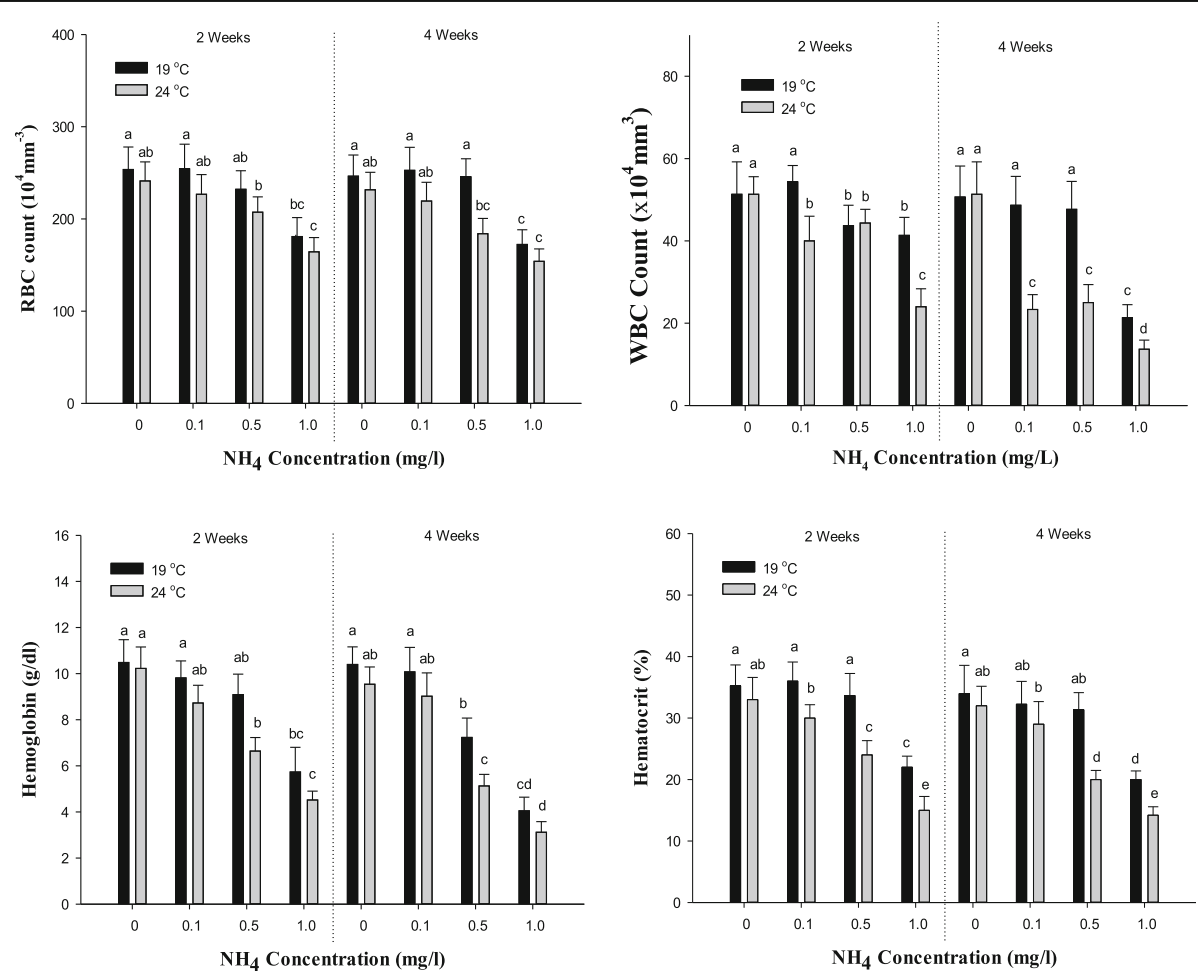

Fig. 2 Change of hematological parameter in rockfish, Sebastes schlegelii, exposed to the different ammonia concentrations and water temperatures. Values with different superscripts are significantly different $(P<0.05)$ as determined by Duncan's multiple range test 


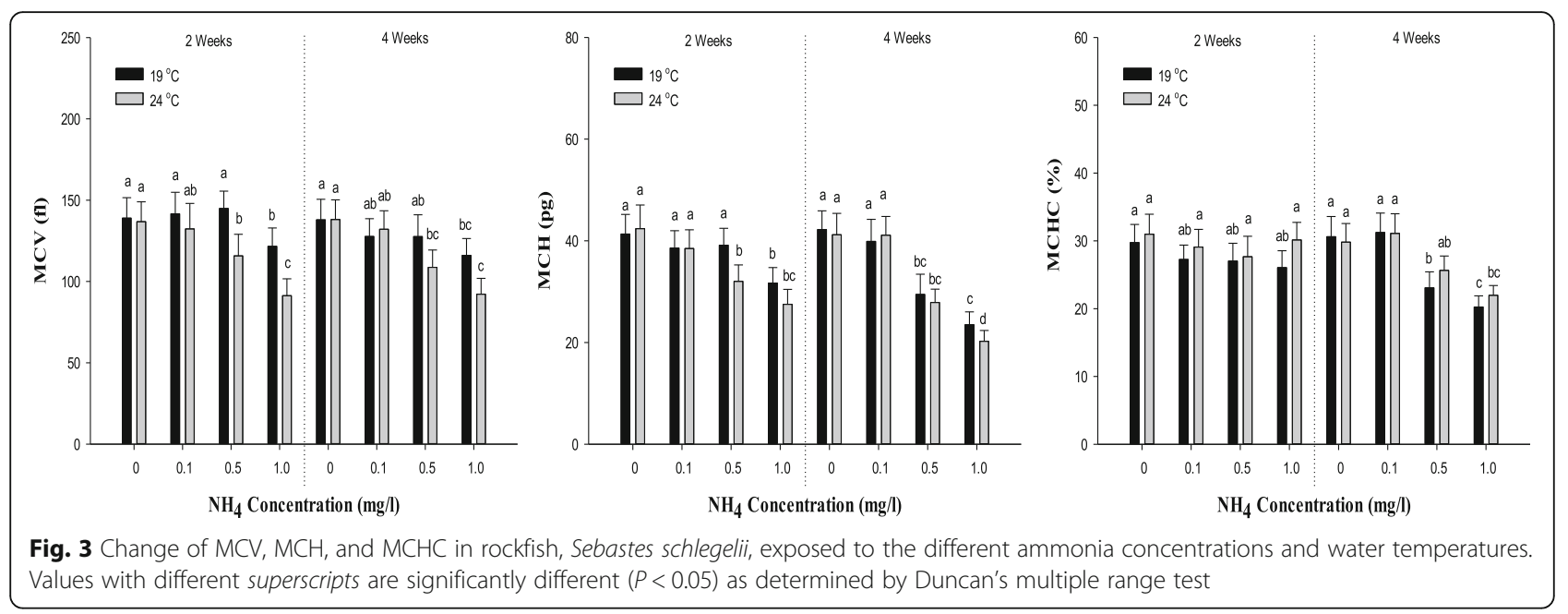

MCHC value, there was no notable alteration after 2 weeks. But, a substantial decline was observed over $0.5 \mathrm{mg} / \mathrm{L}$ of ammonia exposure after 4 weeks. The values of $\mathrm{MCV}, \mathrm{MCH}$ and $\mathrm{MCHC}$ were markedly reduced by the high ammonia exposure and temperature.

\section{Blood ammonia concentration}

The blood ammonia concentration of S. schlegelii is shown in Fig. 4. The blood ammonia concentration of $S$. schlegelii was considerably increased over $0.5 \mathrm{mg} / \mathrm{L}$ at $19{ }^{\circ} \mathrm{C}$ and $0.1 \mathrm{mg} / \mathrm{L}$ at $24{ }^{\circ} \mathrm{C}$ after 2 and 4 weeks. There was no notable alteration according to the difference of temperature except for the concentration of $0.1 \mathrm{mg} / \mathrm{L}$ of ammonia exposure.

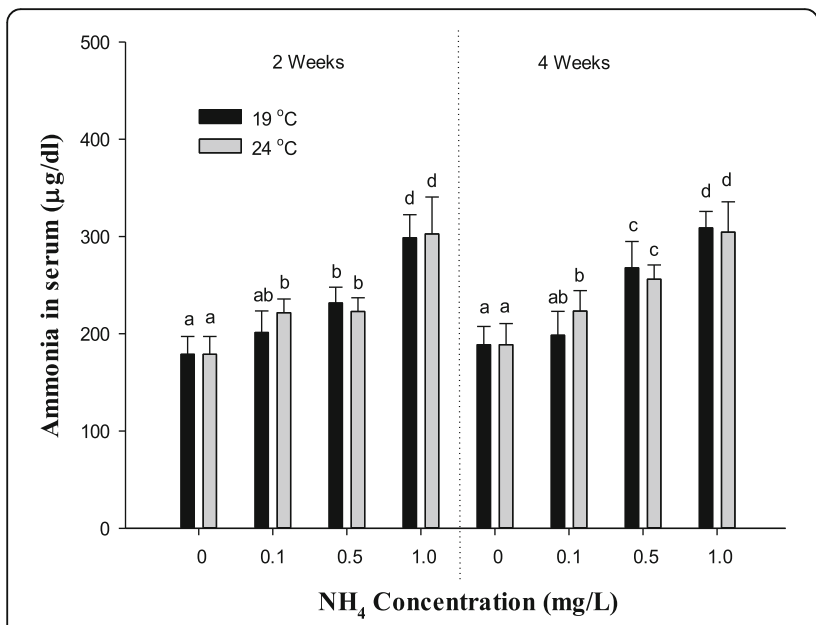

Fig. 4 Change of serum ammonia concentration in rockfish, Sebastes schlegelii, exposed to the different ammonia concentrations and water temperatures. Values with different superscripts are significantly different $(P<0.05)$ as determined by Duncan's multiple range test

\section{Serum components}

The serum inorganic components such as calcium and magnesium of S. schlegelii are shown in Table 2. There was no alteration in calcium and magnesium of $S$. schlegeliiby ammonia exposure depending on temperature. The serum organic components such as total protein and glucose of S. schlegelii are demonstrated in Table 3. In total protein, a notable decrease was observed in the concentration of $1.0 \mathrm{mg} / \mathrm{L}$ at $19{ }^{\circ} \mathrm{C}$ and over $0.5 \mathrm{mg} / \mathrm{L}$ at $24{ }^{\circ} \mathrm{C}$. The total protein was considerably decreased over $0.5 \mathrm{mg} / \mathrm{L}$ at 19 and $24{ }^{\circ} \mathrm{C}$ after 4 weeks. In glucose, a substantial increase was observed in the concentration of $1.0 \mathrm{mg} / \mathrm{L}$ at $19{ }^{\circ} \mathrm{C}$ and over $0.5 \mathrm{mg} / \mathrm{L}$ at $24{ }^{\circ} \mathrm{C}$. The glucose was substantially reduced over $0.5 \mathrm{mg} / \mathrm{L}$ at 19 and $24{ }^{\circ} \mathrm{C}$ after 4 weeks. The serum enzyme components such as GOT and GPT of $S$. schlegelii are shown in Table 4. The GOT was significantly increased over $0.5 \mathrm{mg} / \mathrm{L}$ at 19 and $24{ }^{\circ} \mathrm{C}$ after 2 and 4 weeks. In GPT after 2 weeks, a notable increase was observed over $0.5 \mathrm{mg} / \mathrm{L}$ at $24{ }^{\circ} \mathrm{C}$, whereas there was no change at $19{ }^{\circ} \mathrm{C}$. After 4 weeks, the GPT was considerably increased in the concentration of $1.0 \mathrm{mg} / \mathrm{L}$ at $19{ }^{\circ} \mathrm{C}$ and over $0.5 \mathrm{mg} / \mathrm{L}$ at $24{ }^{\circ} \mathrm{C}$.

\section{Discussion}

The toxicant exposure can induce the inhibition of growth performance in aquatic animals. Erickson et al. (2010) reported a significant reduction of growth performance of rainbow trout, Oncorhynchus mykiss, exposed to arsenic. In this study, the ammonia exposure caused a notable decrease in growth performance of $S$. schlegelii. And, the reduction of growth performance may result from the demand for energy to detoxicate the ammonia which effects the drop in the energy for growth (Clearwater et al. 2002). Also, the growth performance of $S$. schlegelii was affected by the water 
Table 2 Change of serum inorganic substances in rockfish, Sebastes schlegelii, exposed to the different ammonia concentrations and water temperatures. Values with different superscripts are significantly different $(P<0.05)$ as determined by Duncan's multiple range test

\begin{tabular}{|c|c|c|c|c|c|c|c|c|c|}
\hline \multirow[t]{3}{*}{ Parameters } & \multirow{3}{*}{$\begin{array}{l}\text { Period } \\
\text { (weeks) }\end{array}$} & \multicolumn{8}{|c|}{ Ammonia concentration (mg/L) } \\
\hline & & \multicolumn{4}{|l|}{$19^{\circ} \mathrm{C}$} & \multicolumn{4}{|l|}{$24^{\circ} \mathrm{C}$} \\
\hline & & $\overline{0}$ & 0.1 & 0.5 & 1.0 & 0 & 0.1 & 0.5 & 1.0 \\
\hline \multirow{2}{*}{$\begin{array}{l}\text { Calcium } \\
\text { (mg/dL) }\end{array}$} & 2 & $8.44 \pm 0.82^{a}$ & $8.59 \pm 0.67^{\mathrm{a}}$ & $8.76 \pm 0.94^{\mathrm{a}}$ & $7.73 \pm 0.66^{\mathrm{a}}$ & $8.72 \pm 0.79^{a}$ & $7.90 \pm 0.84^{\mathrm{a}}$ & $8.39 \pm 0.56^{a}$ & $8.28 \pm 0.73^{\mathrm{a}}$ \\
\hline & 4 & $8.19 \pm 0.94^{\mathrm{a}}$ & $8.53 \pm 0.61^{\mathrm{a}}$ & $7.93 \pm 0.59^{\mathrm{a}}$ & $8.09 \pm 0.77^{\mathrm{a}}$ & $8.19 \pm 0.76^{a}$ & $8.16 \pm 0.46^{\mathrm{a}}$ & $7.48 \pm 0.94^{\mathrm{a}}$ & $7.51 \pm 0.70^{\mathrm{a}}$ \\
\hline \multirow{2}{*}{$\begin{array}{l}\text { Magnesium } \\
\text { (mg/dL) }\end{array}$} & 2 & $3.18 \pm 0.34^{\mathrm{a}}$ & $3.41 \pm 0.36^{\mathrm{a}}$ & $3.56 \pm 0.33^{\mathrm{a}}$ & $3.42 \pm 0.35^{\mathrm{a}}$ & $3.30 \pm 0.38^{\mathrm{a}}$ & $3.42 \pm 0.44^{\mathrm{a}}$ & $3.57 \pm 0.39^{a}$ & $3.51 \pm 0.31^{\mathrm{a}}$ \\
\hline & 4 & $3.26 \pm 0.37^{\mathrm{a}}$ & $3.41 \pm 0.36^{\mathrm{a}}$ & $3.45 \pm 0.37^{\mathrm{a}}$ & $3.47 \pm 0.27^{\mathrm{a}}$ & $3.37 \pm 0.37^{\mathrm{a}}$ & $3.50 \pm 0.35^{\mathrm{a}}$ & $3.71 \pm 0.31^{a}$ & $3.49 \pm 0.32^{\mathrm{a}}$ \\
\hline
\end{tabular}

temperature change. Carvalho and Fernandes (2006) reported that the high temperature causes the severe accumulation in fish by the toxicant exposure, which may need the more energy for detoxification.

The biochemical and physiological alterations in fish blood can be occurred by the toxic substances in an aquatic environment, and the blood parameters can be a sensitive and reliable indicator to evaluate the physiological status of fish (Mazon et al. 2002. Vosyliene and Kazlauskiene (2004) reported a negative change in blood chemistry of rainbow trout, O. mykiss, exposed to ammonia. In this study, the RBC count, WBC count, hemoglobin, and hematocrit of S. schlegelii were substantially decreased by ammonia exposure. Tilak et al. (2007) also reported a substantial decrease in hemoglobin of common carp, Cyprinus carpio, exposed to ammonia, which is caused by the increase in the oxygen intake and elevation in methemoglobin by gill damage. Thangam et al. (2014) reported a notable reduction in RBC and WBC count of common carp, C. carpio, exposed to ammonia. $\mathrm{RBC}$ count decreased due to anemia leading to inhibition of erythropoietin, and WBC count also decreased by the leucopenia coupled with stress for toxicants in aquatic animals. Knoph and Thorud (1996) reported that Atlantic salmon, Salmo salar, when exposed to ammonia showed decreased hematocrit resulting from reduction in $\mathrm{RBC}$ count. The ammonia exposure also caused a notable reduction in $\mathrm{MCV}$, $\mathrm{MCH}$, and $\mathrm{MCHC}$ of S. schlegelii. Saravanan et al. (2011) suggested that the diazinon pesticide exposure to
European catfish, Cyprinus carpio resulted in a considerable decrease in $\mathrm{MCV}, \mathrm{MCH}$, and $\mathrm{MCHC}$, which is due to the increase of immature red blood cells by the toxicant exposure. In this study, the temperature in addition to the ammonia concentration substantially affected the hematological parameters of S. schlegelii. Adeyemo et al. (2003) reported that temperature decreases both the quantity and quality of erythrocytes and hemoglobin, which cause deteriorated oxygen supply. Carvalho and Fernandes (2006) suggested that a high temperature considerably affected the hematological values of Prochilodus scrofa exposed to copper result in the increased diffusion rate, chemical reactions, and increased oxygen transport at a high temperature.

The ammonia exposure induced a significant accumulation in the blood of S. schlegelii. Lemarie et al. (2004) also reported a considerable ammonia accumulation in the blood of juvenile sea bass, Dicentrarchus labrax, exposed to ammonia, which should negatively affect the experimental animal. The ammonia concentration notably affected the ammonia accumulation in the blood of S. schlegelii, but there was no significant change in the ammonia accumulation in the blood according to the temperature.

The inorganic serum components such as calcium and magnesium have been considered as critical indicators to assess the toxicity of substances, which also act as the ion regulator for homeostasis (Kim and Kang 2015). In inorganic serum components, there was no alteration in calcium and magnesium of $S$. schlegelii exposed

Table 3 Change of serum organic substances in rockfish, Sebastes schlegelii, exposed to the different ammonia concentrations and water temperatures. Values with different superscripts are significantly different $(P<0.05)$ as determined by Duncan's multiple range test

\begin{tabular}{|c|c|c|c|c|c|c|c|c|c|}
\hline \multirow[t]{3}{*}{ Parameters } & \multirow{3}{*}{$\begin{array}{l}\text { Period } \\
\text { (weeks) }\end{array}$} & \multicolumn{8}{|c|}{ Ammonia concentration (mg/L) } \\
\hline & & \multicolumn{4}{|l|}{$19^{\circ} \mathrm{C}$} & \multicolumn{4}{|l|}{$24^{\circ} \mathrm{C}$} \\
\hline & & 0 & 0.1 & 0.5 & 1.0 & 0 & 0.1 & 0.5 & 1.0 \\
\hline \multirow{2}{*}{$\begin{array}{l}\text { Total protein } \\
(\mathrm{mg} / \mathrm{mL})\end{array}$} & 2 & $0.39 \pm 0.01^{a}$ & $0.37 \pm 0.02^{\mathrm{a}}$ & $0.37 \pm 0.02^{\mathrm{a}}$ & $0.31 \pm 0.04^{b}$ & $0.39 \pm 0.02^{\mathrm{a}}$ & $0.38 \pm 0.03^{\mathrm{a}}$ & $0.31 \pm 0.03^{b}$ & $0.30 \pm 0.03^{b}$ \\
\hline & 4 & $0.37 \pm 0.02^{\mathrm{a}}$ & $0.38 \pm 0.03^{\mathrm{a}}$ & $0.30 \pm 0.02^{b}$ & $0.29 \pm 0.02^{b}$ & $0.39 \pm 0.04^{\mathrm{a}}$ & $0.39 \pm 0.03^{\mathrm{a}}$ & $0.29 \pm 0.02^{b}$ & $0.28 \pm 0.02^{b}$ \\
\hline \multirow{2}{*}{$\begin{array}{l}\text { Glucose } \\
(\mathrm{mg} / \mathrm{mL})\end{array}$} & 2 & $30.70 \pm 4.10^{\mathrm{a}}$ & $31.74 \pm 4.50^{\mathrm{a}}$ & $30.59 \pm 4.80^{\mathrm{a}}$ & $49.47 \pm 3.20^{\mathrm{b}}$ & $32.46 \pm 4.26^{\mathrm{a}}$ & $32.84 \pm 3.46^{\mathrm{a}}$ & $47.65 \pm 6.80^{b}$ & $50.32 \pm 5.10^{b}$ \\
\hline & 4 & $29.57 \pm 5.70^{\mathrm{a}}$ & $31.66 \pm 5.90^{\mathrm{a}}$ & $48.12 \pm 6.20^{b}$ & $49.04 \pm 4.30^{b}$ & $29.91 \pm 4.60^{\mathrm{a}}$ & $30.58 \pm 3.60^{\mathrm{a}}$ & $50.72 \pm 3.80^{b}$ & $50.79 \pm 5.10^{b}$ \\
\hline
\end{tabular}


Table 4 Change of serum enzyme activity in rockfish, Sebastes schlegelii, exposed to the different ammonia concentrations and water temperatures. Values with different superscript are significantly different $(P<0.05)$ as determined by Duncan's multiple range test

\begin{tabular}{|c|c|c|c|c|c|c|c|c|c|}
\hline \multirow[t]{3}{*}{ Parameters } & \multirow{3}{*}{$\begin{array}{l}\text { Period } \\
\text { (weeks) }\end{array}$} & \multicolumn{8}{|c|}{ Ammonia concentration (mg/L) } \\
\hline & & \multicolumn{4}{|l|}{$19^{\circ} \mathrm{C}$} & \multicolumn{4}{|l|}{$24^{\circ} \mathrm{C}$} \\
\hline & & 0 & 0.1 & 0.5 & 1.0 & $\overline{0}$ & 0.1 & 0.5 & 1.0 \\
\hline \multirow[t]{2}{*}{ GOT (Karmen/mL) } & 2 & $4.25 \pm 0.64^{a}$ & $4.65 \pm 0.45^{a}$ & $6.32 \pm 0.33^{b}$ & $6.29 \pm 0.65^{b}$ & $4.21 \pm 0.64^{a}$ & $4.06 \pm 0.43^{a}$ & $5.95 \pm 0.48^{b}$ & $8.44 \pm 1.06^{c}$ \\
\hline & 4 & $4.51 \pm 0.68^{\mathrm{a}}$ & $4.61 \pm 0.63^{\mathrm{a}}$ & $5.80 \pm 0.67^{b}$ & $8.13 \pm 0.73^{c}$ & $4.36 \pm 0.53^{\mathrm{a}}$ & $4.65 \pm 0.42^{\mathrm{a}}$ & $6.23 \pm 0.54^{b}$ & $8.63 \pm 0.78^{c}$ \\
\hline \multirow[t]{2}{*}{ GPT (Karmen/mL) } & 2 & $5.41 \pm 0.67^{a}$ & $5.30 \pm 0.56^{a}$ & $5.34 \pm 0.62^{a}$ & $5.12 \pm 0.44^{a}$ & $5.37 \pm 0.43^{a}$ & $4.97 \pm 0.35^{\mathrm{a}}$ & $5.15 \pm 0.57^{b}$ & $9.47 \pm 0.78^{c}$ \\
\hline & 4 & $5.76 \pm 0.55^{\mathrm{a}}$ & $5.45 \pm 0.58^{a}$ & $5.79 \pm 0.38^{\mathrm{a}}$ & $10.94 \pm 1.30^{b}$ & $5.65 \pm 0.75^{a}$ & $5.83 \pm 0.61^{a}$ & $13.02 \pm 1.26^{c}$ & $11.04 \pm 1.32^{b}$ \\
\hline
\end{tabular}

ammonia. Knoph and Thorud (1996) also reported no significant change in calcium and magnesium of Atlantic salmon, S. salar, exposed to ammonia for 2 weeks, whereas a notable increase in calcium and magnesium was observed after 2-3 days of exposure time. Thus, our studies showed that exposure at 2 and 4 weeks was not influenced in plasma, calcium, and magnesium concentrations. The organic components such as total protein and glucose can be a reliable biomarker to detect animal health (Oner et al. 2007). In organic serum components, the total protein of S. schlegelii was significantly decreased by ammonia exposure, whereas the glucose of S. schlegelii was increased. Gopal et al. (1997) suggested that total plasma has been notably changed under stress situations. The increase in glucose may be a consequence of glycogenolytic activity of catecholamines and gluconeogenetic effect of glucocorticoids by the stress response under toxic substance exposure (Dobsikova et al. 2011). The GOT and GPT in serum components can be generally used to assess the tissue damage of the liver and kidney (Agrahari et al. 2007). In enzyme serum components, the GOT and GPT of $S$. schlegelii was significantly increased by the ammonia exposure. Vedel et al. (1998) also reported a considerable increase in the GOT and GPT of rainbow trout, O. mykiss, exposed to ammonia, indicated some degree of tissue necrosis. The temperature as well as the concentration of ammonia exposure notably affected the alterations of serum components of $S$. schlegelii, showing that the temperature also can be a critical factor to affect the experimental animals.

\section{Conclusions}

The ammonia exposure to S. schlegelii depending on water temperature induced notable decreases in growth performance (daily length gain, daily weight gain, condition factor, and hepatosomatic index) hematological parameters (RBC count, WBC count, hemoglobin, and hematocrit) and significant alterations in serum components (total protein, glucose, GOT, and GPT). Considering the results of this study, the ammonia depending on water temperature should negatively influence the experimental fish, S. schlegelii.

\section{Abbreviations}

GOT: Glutamic oxalate transaminase; GPT: Glutamic pyruvate transaminase; Hb: Hemoglobin; HIS: Hepatosomatic Index; Ht: Hematocrit; MCH: Mean corpuscular hemoglobin; MCHC: Mean corpuscular hemoglobin concentration; MCV: Mean corpuscular volume; RBC: Red blood cell; WBC: White blood cell

\section{Acknowledgements}

This work was supported by a grant from the National Institute of Fisheries Science (R2016069).

\section{Authors' contributions}

$\mathrm{SH}$ and $\mathrm{KW}$ carried out the environmental toxicity studies and manuscript writing. JH participated in the design of the study and data analysis. SD participated in the collection and assembly of the data; JC participated in its design and coordination and helped to draft the manuscript. All authors read and approved the final manuscript.

\section{Competing interests}

The authors declare that they have no competing interests.

\section{Consent for publication}

Not applicable.

\section{Ethics approval}

All experimental animals used in this study were maintained under a protocol approved by the Institutional Animal Care and Use Committee of Pukyong National University.

\section{Disclosure}

The dataset(s) supporting the conclusions of this article is not included in the article.

\section{Author details}

${ }^{1}$ Department of Aquatic Life Medicine, Pukyong National University, Busan 608-737, Republic of Korea. ${ }^{2}$ Aquatic life disease control division, National Fisheries Research and Development Institute, Busan 619-902, Republic of Korea.

Received: 18 October 2016 Accepted: 2 December 2016

Published online: 15 December 2016

\section{References}

Adeyemo OK, Agbede SA, Olaniyan AO, Shoaga OA. The haematological response of Clarias gariepinus to change in acclimation temperature. Afr J Biomed Res. 2003;6:105-8.

Agrahari S, Pandey KC, Gopal K. Biochemical alteration induced by monocrotophos in the blood plasma of fish, Channa punctatus (Bloch). Pestic Biochem Physiol. 2007;88:268-72.

Ajani F. Hormonal and haematological responses of Clarias gariepinus (Burchell 1822) to nitrite toxicity. Afr J Biotechnol. 2008;7(19):3466-71.

Barbieri E, Bondioli ACV. Acute toxicity of ammonia in Pacu fish (Piaractus mesopotamicus, Holmberg, 1887) at different temperatures levels. Aquac Res. 2015:8:565-71. 
Carvalho CS, Fernandes MN. Effect of temperature on copper toxicity and hematological responses in the neotropical fish Prochilodus scrofa at low and high pH. Aquaculture. 2006;251:109-17.

Clearwater SJ, Farag AM, Meyer JS. Bioavailability and toxicity of dietborne copper and zinc to fish. Comparative Biochemistry and Physiology - C Toxicology and Pharmacology. 2002;132(3):269-313.

Delos C, Erickson R. Update of ambient water quality criteria for ammonia. EPA/ 822/R-99/014. Final/technical report. Washington, DC: U.S. Environmental ProtectionAgency; 1999

Dobsikova R, Blahova J, Modra H, Skoric M, Svobodova Z. The effect of acute exposure to herbicide Gardoprim Plus Gold 500 SC on haematological and biochemical indicators and histopathological changes in common carp (Cyprinus carpio L.). Journal of the University of Veterinary and Pharmaceutical Sciences in Brno. 2011;80:359-63.

Duncan DB. Multiple range and multiple $f$ tests. Biometrics. 1955;11:1-42.

El-Shafai SA, El-Gohary FA, Nasr FA, Van Der Steen NP, Gijzen HJ. Chronic ammonia toxicity to duckweed-fed tilapia (Oreochromis niloticus). Aquaculture. 2004;232(1-4):117-27.

Erickson RJ, Mount DR, Highland TL, Hockett JR, Leonard EN, Mattson VR, Dawson TD, Lott KG. Effects of copper, cadmium, lead, and arsenic in a live diet on juvenile fish growth. Can J Fish Aquat Sci. 2010;67(11):1816-26.

Gopal V, Parvathy S, Balasubramanian PR. Effect of heavy metals on the blood protein biochemistry of the fish Cyprinus carpio and its use as abio-indicator of pollution stress. Environ Monit Assess. 1997;48:117-24.

Kim JH, Kang JC. The selenium accumulation and its effect on growth, and Haematological parameters in red seabream, Pagrus major, exposed to water borne selenium. Ecotoxicol Environ Saf. 2014;104:96-102.

Kim JH, Kang JC. The lead accumulation and hematological findings in juvenile rock fish Sebastes schlegelii exposed to the dietary lead(II) concentrations. Ecotoxicol Environ Saf. 2015;115:33-9.

Knoph MB, Thorud K. Toxicity of ammonia to Atlantic salmon (Salmo salar L.) in seawater-effects on plasma osmolality, ion, ammonia, urea and glucose levels and hematologic parameters. Comp Biochem Physiol A Physiol. 1996; 113(4):375-81.

Lemarie G, Dosdat A, Coves D, Dutto G, Gasset E, Person-Le Ruyet J. Effect of chronic ammonia exposure on growth of European seabass (Dicentrarchus labrax) juveniles. Aquaculture. 2004;229(1-4):479-91.

Li M, Yu N, Qin JG, Li E, Du Z, Chen L. Effects of ammonia stress, dietary linseed oil and Edwardsiella ictaluri challenge on juvenile darkbarbel catfish Pelteobagrus vachelli. Fish and Shellfish Immunology. 2014;38(1):158-65.

Mazon AF, Monteiro EAS, Pinheiro GHD, Fernandes MN. Hematological and physiological changes induced by short-term exposure to copper in the freshwater fish, Prochilodus scrofa. Brazilian Journal of Biology = Revista Brasleira de Biologia. 2002;62(4A):621-31.

Oner M, Alti G, Canli M. Changes in serum in biochemical parameters of freshwater fish Oreochromis niloticus following prolonged metal (Ag, Cd, Cr, Cu, Zn) exposures. Environ Toxicol Chem. 2007;27(2):360-6.

Patra RW, Chapman JC, Lim RP, Gehrke PC, Sunderam RM. Interactions between water temperature and contaminant toxicity to freshwater fish. Environ Toxicol Chem. 2015;34(8):1809-17.

Randall DJ, Tsui TKN. Ammonia toxicity in fish. Mar Pollut Bull. 2002;45(1-12):17-23.

Richardson J. Acute ammonia toxicity for eight New Zealand indigenous freshwater species. N Z J Mar Freshw Res. 1997;31(2):185-90.

Ruyet PLJ, Chartois H, Quemener L. Comparative acute ammonia toxicity in marine fish and plasma ammonia response. Aquaculture. 1995;136(1-2): 181-94.

Saravanan M, Prabhu Kumar K, Ramesh M. Haematological and biochemical responses of freshwater teleost fish Cyprinus carpio (Actinopterygii: Cypriniformes) during acute and chronic sublethal exposure to lindane. Pestic Biochem Physiol. 2011;100(3):206-11.

Sinha AK, Liew HJ, Diricx M, Blust R, De BG. The interactive effects of ammonia exposure, nutritional status and exercise on metabolic and physiological responses in gold fish (Carassius auratus L.). Aquat Toxicol. 2012;109:33-46.

Thangam Y, Perumayee M, Jayaprakash S, Umavathi S, Basheer SK. Studies of ammonia toxicity on haematological parameters to freshwater fish Cyprinus carpio (common carp). International jounal of current mocrobiology and applied sciences. 2014;3(12):535-42.

Tilak KS, Veeraiah K, Milton Prema Raju J. Effects of ammonia, nitrite and nitrate on hemoglobin content and oxygen consumption of freshwater fish, Cyprinus carpio (Linnaeus). J Environ Biol. 2007;28(1):45-7.
Vedel NE, Korsgaard B, Jensen FB. Isolated and combined exposure to ammonia and nitrite in rainbow trout (Oncorhynchus mykiss): effects on electrolyte status, blood respiratory properties and brain glutamine:glutamate concentrations. Aquat Toxicol. 1998:41:325-42.

Vosyliene MZ, Kazlauskiene N. Comparative studies of sublethal effects of ammonia on rainbow trout (Oncorhynchus mykiss) at different stages of its development. Acta Zoologica Lituanica. 2004;14(1):13-8.

Wilkie MP. Mechanisms of ammonia excretion across fish gills. Comp Biochem Physiol A Physiol. 1997;Comp. Biochem. Physiol. A: Physiol. 118(1):39-50.

\section{Submit your next manuscript to BioMed Central and we will help you at every step:}

- We accept pre-submission inquiries

- Our selector tool helps you to find the most relevant journal

- We provide round the clock customer support

- Convenient online submission

- Thorough peer review

- Inclusion in PubMed and all major indexing services

- Maximum visibility for your research

Submit your manuscript at www.biomedcentral.com/submit
) Biomed Central 